\title{
Early Progress in Aphid Genomics and Consequences for Plant-Aphid Interactions Studies
}

\author{
Denis Tagu, ${ }^{1}$ John P. Klingler, ${ }^{2}$ Andrès Moya, ${ }^{3}$ and Jean-Christophe Simon ${ }^{1}$ \\ ${ }^{1}$ INRA Rennes, UMR BiO3P, INRA, Agrocampus Rennes, Université Rennes 1, Biologie des Organismes et des Populations \\ Appliquées à la Protection des Plantes, BP 35327, F-35653 Le Rheu Cedex, France; ${ }^{2}$ Department of Plant Sciences, \\ University of Arizona, Tucson 85721, U.S.A.; ${ }^{3}$ Institut Cavanilles de Biodiversitat i Biologia Evolutiva (I.C.B.I.B.E.), \\ Universitat de Valencia, Apartado de Correos 2085, 46071 Valencia, Spain
}

Submitted 24 January 2008. Accepted 26 February 2008.

\begin{abstract}
Aphids occupy a niche comprising two conceptual realms: a micron-scale feeding site beneath the plant surface, in which a syringe-like appendage mediates chemical exchange with a specific plant cell type; and the larger realm of a metazoan with sensory organs, a nervous system, and behavior, all responsive to the condition of the host plant and the broader environment. The biology that connects these realms is not well understood, but new details are emerging with the help of genomic tools. The power of these tools is set to increase substantially now that the first genome of an aphid is being sequenced and annotated. This has been possible because a community of aphid researchers focused their efforts to develop and share genomic resources through an international consortium. This complete genome sequence, along with other resources, should permit major advances in understanding the complex and peculiar biological traits responsible for aphids' evolutionary success and their damaging effects on agriculture. This review highlights early progress in the application of aphid genomics and identifies key issues of plant-aphid interactions likely to benefit as molecular tools are further developed. Use of this new knowledge could make significant contributions to crop protection against these and other phloemfeeding insects.
\end{abstract}

Additional keywords: Acyrthosiphon pisum, parthenogenesis, phenotypic plasticity, resistance, symbiont, virus

"Dès le premier jour, environ les sept heures du soir, je vis avec un grand contentement qu'il était accouché : et dès lors je crus devoir lui donner le nom de Puceronne." (Translation: "On the first day, around seven in the evening, I saw with great satisfaction that 'he' had given birth: and from that moment I believed I should give 'him' the name Puceronne [female aphid].") (Charles Bonnet, Traité d'insectologie ou observation sur les pucerons, 1745)

Aphids are phloem-feeding insects that cause major damage to plants around the world. The concept of community metagenome can be applied to aphids because they occupy a key node of an interactive network linking the host plants they feed on, endosymbiotic bacteria they harbor, plant viruses they passively transmit, and natural enemies they fight. These biotic

Corresponding author: Denis Tagu, E-mail: denis.tagu@ rennes.inra.fr interactions are largely dependent on abiotic factors that drive the expression of a wide spectrum of phenotypic plasticities in the aphid. Within this interaction network, genomics tools already have been developed for aphid host plants (e.g., Arabidopsis thaliana and Medicago truncatula), aphid-transmitted plant viruses (e.g., Barley yellow dwarf virus [BYDV]), and aphid endosymbiotic bacteria (Buchnera aphidicola). Until recently, the central node represented by aphid genomics has been missing. Today, this gap is being filled partially with the development of several genomic tools, including the sequencing of an aphid genome. This review surveys the new field of aphid genomics in the context of aphid interactions with plants. In particular, it aims at describing i) new insights into the distinctive biological traits of aphids that have allowed their evolutionary success and status as major pests and ii) the genomic tools that are opening new avenues for progress in aphid biology and that may allow new approaches to crop protection against parasitism of the phloem.

Fearsome plant enemies, but fascinating creatures.

The aphid clade arose within the order Hemiptera over 250 million years ago and underwent a great diversification much later, simultaneously with that of the angiosperms (Dixon 1998). Aphids have fascinated biologists for centuries and are the best studied of the phloem-feeding insects. Their exceptional phenotypic and developmental plasticity, which has contributed to the status of many species as major agricultural pests, also makes aphids useful models for study within the basic life sciences. Aphids have been the subject of pioneering observations of noted figures in science like René Antoine Ferchault de Réaumur and Anton van Leeuwenhoek, who erroneously described aphids as hermaphrodites, or geneticist Thomas Hunt Morgan, who first observed aphid chromosomes (Morgan 1910). Parthenogenesis was discovered in aphids in the 18th century by Charles Bonnet, and animal photoperiodism first was found in aphids in the early 20th century (Marcovitch 1924). The plasticity made possible by these life history traits renders the aphid an ideal organism to study genome expression remodeling under a changing environment. The pea aphid (Acyrthosiphon pisum), in particular, is gaining stature as a model system for research topics ranging from symbiosis and vector biology to the genetics of host adaptation and speciation (Brisson and Stern 2006). Genomic tools, which soon will include an annotated genome sequence of the pea aphid, are offering good opportunities to explore the molecular biology of aphid interactions with plants. 
Today, aphids attack cultivated, ornamental, and forest plants, ranging across gymnosperms and angiosperms. Like other members of the suborder Sternorrhyncha, which includes whiteflies, psyllids, and scale insects, aphids have highly elongated, specialized mouthparts adapted for locating sieve tubes of the phloem, from which they draw a nutritionally dilute sap. They can cause severe plant damage directly by feeding activities or by transmitting plant viruses. Aphids can have a particularly high rate of population growth, made possible by their vivipary and cyclical parthenogenesis. In addition, the aphid developmental program is telescoped in that oocytes already are developing inside unborn female embryos, resulting in generation times as short as a few days. This asexual, viviparous mode of reproduction can result in single aphids giving rise to clonal lineages infesting vast areas of monoculture within a few weeks of landing in a field.

Aphid herbivory costs hundreds of millions of dollars in agricultural damage each year, with losses varying greatly among countries and aphid species. In Great Britain, average annual losses attributable to aphids are on the order of $£ 100$ million whereas, in the United States, losses due only to the Russian wheat aphid (Diuraphis noxia) were estimated at approximately $\$ 200$ million (Tatchell 1991). In addition to direct damage by aphid feeding, aphid-transmitted viruses cause economic losses at least as severe. In the United States, BYDV caused average annual losses on cereal production of \$42 million (Lister and Ranoeri 1995).

To reduce the environmental and economical costs of insecticides, cultivated plants have been bred for resistance against aphids and the many viruses they spread. However, aphid pests regularly are reported to overcome plant resistance genes identified in crop breeding trials and subsequently released in new cultivars. For example, breeding for durable resistance to greenbug (Schizaphis graminum) and Russian wheat aphid in cereals is challenged by the fast emergence of new damaging biotypes (Smith et al. 2004). In the absence of genetic plant resistance, insecticide treatments remain the easiest and cheapest way to control aphid infestations. Insecticide use varies widely from one crop to another and its efficiency in protecting cultivated plants can vary from 20 to $95 \%$ (Derron and Goy 1993). In 2001, two-thirds of the cereal fields in central France were repeatedly treated (up to 10 times) with insecticides to control aphids whereas they were only treated 4 to 7 times in 1994. However, aphid populations may rapidly evolve resistance to insecticides. For example, the green peach aphid (Myzus persicae) has evolved resistances to more insecticides than any other insect (Anstead et al. 2005).

Genomic approaches to study plant responses to phloem feeders are well established and have been discussed in recent reviews (de Vos et al. 2007; Goggin 2007; Kaloshian and Walling 2005; Thompson and Goggin 2006). Many studies have shown that phloem feeders elicit distinct macroscopic and molecular responses from their hosts that, in some respects, place them in a category of pests that overlaps the realms of microbial pathogens and chewing insects. In general, phloem feeding can cause the activation of plant defense networks controlled by hormones such as salicylic acid, jasmonic acid, and ethylene, but the particular transcript profiles vary substantially among different species combinations and often are distinct from those induced by either microbes or chewing insects. Studies of plant mutants, particularly in Arabidopsis thaliana, have identified genes and signal pathways important in basal defense mechanisms against aphids (de Vos et al. 2007; Pegadaraju et al. 2005, 2007) and whiteflies (Kempena et al. 2007; Zarate et al. 2007). Plant molecular responses to phloem feeding suggest that these insects expose plants to specific defense elicitors, although none have yet been identified.
Major gene resistance to aphids in plants.

Host resistance to aphids that is controlled by major genes has been identified frequently in crop germplasm (Puterka and Burton 1991) and is a feature that aligns these insects more closely with pathogens and distinguishes them from chewing insects. The common appearance of aphid biotypes that can overcome these forms of resistance is consistent with the plant-pathogen model of gene-for-gene interaction. The relevance of this model increased with the discovery that $M i-1$, a dominant resistance gene against Meloidogyne spp. of root knot nematodes in tomato, also confers resistance to specific isolates of the potato aphid (Macrosiphum euphorbiae) (Rossi et al. 1998). Mi- 1 encodes a member of the largest group of plant resistance proteins, known as the nucleotide-binding site leucine-rich repeat (NBS-LRR) superfamily, other members of which confer resistance against a diverse range of microbial pathogens. In addition to nematodes and an aphid species, $M i-1$ also conditions resistance against whitefly biotypes (Nombela et al. 2003) and a psyllid (Casteel et al. 2006), all metazoan parasites of phloem tissue. A dominant resistance gene against the cotton-melon aphid (Aphis gossypii) in melon, called Vat, is also a member of this superfamily (Dogimont et al. 2007). These findings show that plants have recruited components of their innate immune systems to defend against parasitism of the phloem tissue. This form of resistance to phloem feeding is likely to be common, because genetic analyses of other plantaphid interactions have shown tight linkage between aphid resistance loci and NBS-LRR gene clusters (Brotman et al. 2002; Cevik and King 2002; Klingler et al. 2005, 2007; Seah et al. 1998).

\section{The aphid-plant cell interface.}

Like plant-parasitic nematodes, phloem feeders secrete saliva from their mouthparts, called stylets, into their target plant tissues. They salivate as soon as they first probe through the outer tissue on a path to the phloem, occasionally puncturing cells for a few seconds at a time, but primarily passing between cells by penetrating cell walls and middle lamellae (Tjallingii 2006). The insect stylet is exquisitely narrowed to a diameter of only a few microns; salivation directly into sieve elements can be likened to the injection of bacterial proteins into host cells via the type III secretion system. Phloem feeders clearly have evolved mechanisms to evade or actively suppress plant defenses because an individual stylet-sieve element contact, or feeding site, can endure for days at a time. A number of protein classes have been identified in aphid saliva, including lipoproteins, phenoloxidases, and pectinases (Cherqui and Tjallingii 2000; Miles 1999). As with microbial pathogens, aphid saliva contains proteins or other factors that promote colonization of the host (Tjallingii 2006), some of which may be involved in gene-for-gene interactions. Ultimately, these factors might play a role in determining colonization success at the species level and, thus, influence the host range of aphids.

The molecular nature of such factors recently was described in an elegant study by Will and associates (2007), in which calcium-binding proteins were identified in the saliva of the vetch aphid (Megoura viciae). The secretion of these proteins during aphid feeding correlates with the suppression of sieve element plugging that normally is carried out by protein bodies (called forisomes) that disperse when the cell is punctured. Commonly found in the sieve elements of legumes, forisomes can reversibly alternate between a contracted, crystalline form and a dispersed, sieve plate-occluding form in a calciumdependent manner (Knoblauch et al. 2001; Will and van Bel 2006). Whereas mechanical puncture of a sieve element by a microcapillary tip can trigger an increase in $\mathrm{Ca}^{2+}$ within the sieve element and a concomitant dispersal of forisomes, the 
calcium-binding activity of aphid saliva appears to counteract the perturbation from a cell puncture by lowering the sieve element's free $\mathrm{Ca}^{2+}$ concentration. Low $\mathrm{Ca}^{2+}$ levels maintain forisomes in their contracted, crystalline state, which keeps the sieve tube flowing even in the presence of an intruding stylet. This is a clear demonstration of how specific salivary components of phloem feeders may serve as host utilization factors, analogous to microbial virulence factors. The discovery of these proteins in aphid saliva provides a significant point of access for the application of genomic tools to characterize and manipulate events at the aphid-plant cell interface.

In another recent study, biochemical fractions extracted from Russian wheat aphids were injected into wheat seedlings to test their ability to impose plant stunting and other damage symptoms (Lapitan et al. 2007). Damage symptoms were compared between two wheat cultivars that differ in the presence or absence of a dominant resistance gene against the aphid, called $D n 7$. The results suggest that the protein fraction from whole aphids was responsible for leaf rolling, stunted growth, and defense-related enzyme induction in the wheat seedlings. The Dn7-containing line was resistant to alterations in plant growth and also expressed higher levels of defense-related enzyme activities in response to proteinaceous aphid extracts. These results are consistent with previous work on wheat responses to Russian wheat aphid infestation, and suggest an interaction between $D n 7$ and a protein or proteins within the aphid-possibly a salivary factor. Unfortunately, the degree of relatedness between the two wheat genotypes was not specified in this report; therefore, it is unclear whether other genes besides $D n 7$ may be involved in the differential plant reactions to aphid extracts. Nevertheless, this study offers the prospect of identifying specific virulence factors from a highly destructive aphid species. Outcomes could include the identification of interactions between aphid virulence proteins and plant resistance proteins, as well as the elucidation of the role of overt damage symptoms (e.g., leaf rolling or chlorosis) in aphid colonization of the host.

\section{Endosymbioses.}

Phloem sap provides an unbalanced diet for aphids: it is rich in carbon (mainly sucrose) and nitrogen (mainly amino acids), but poor in several essential amino acids such as leucine, tryptophan, or methionine (Douglas 2003). Over 150 million years ago, aphids evolved a mutualistic association with the bacteria B. aphidicola, which live within specialized, polyploid aphid cells called bacteriocytes. The genus Buchnera has one of the smallest known bacterial genomes $(0.45$ to $0.67 \mathrm{Mb})$, due to massive gene losses typical of endosymbiotic lineages. The genes encoding biosynthesis of essential amino acids are still present, suggesting that the symbiotic interaction is based mainly on nutritional exchange between a Buchnera bacterium and its aphid host (Baumann 2005). For example, up to $90 \%$ of essential amino acids needed by the pea aphid are provided by Buchnera spp. (Douglas 2006). "Curing" aphids of their symbionts by feeding them antibiotics resulted in stunted growth and failed reproduction, a result that underscores the obligate interdependence of these organisms.

Genomic approaches have led to significant progress in understanding this symbiosis, made possible largely with sequence information from Buchnera genomes (Shigenobu et al. 2000; Tamas et al. 2002). Several studies have focused on the interplay between the aphid host and symbiont genomes. For example, expression patterns of homologs of well-known insect transcription factors-important in insect developmentwere determined in developing pea aphid bacteriocytes, with the results showing unusual patterns reflecting the unique developmental pathway of these cells (Braendle et al. 2003).
More recently, a transcriptomic analysis of bacteriocytes was performed to establish a catalogue of expressed sequence tags (EST) from these specialized cells (Nakabachi et al. 2005). A number of genes encoding proteins involved in amino acid metabolism, amino acid transport, and cell-wall-degrading enzymes have been identified, demonstrating the essential involvement of bacteriocyte cells in the symbiotic relationship with Buchnera spp. Modification in amino acid contents of the aphid diet triggered a very low transcriptional response of the Buchnera genome. The only gene significantly regulated by amino acid diet is involved in methionine biosynthesis which is also one of the rare genes which has its regulator in the Buchnera genome (Moran et al. 2005). A global diminution of essential amino acids combined with a modification in sucrose concentration of the diet did not show a clear adaptation of the Buchnera transcriptome (Reymond et al. 2006), suggesting complex interaction between the host and the bacteria to regulate primary metabolism and nutrition.

Recently, a dual-genome microarray, composed of sequences from the pea aphid and its resident Buchnera spp. (Wilson et al. 2006), was used to explore gene expression differences between pea aphid strains (Dunbar et al. 2007). With this approach, a single nucleotide deletion in the Buchnera genome from one aphid strain, compared with that of another, was shown to have dramatic effects on the heat tolerance of the pea aphid. The deletion lies within the promoter of a heat-shock gene, causing a substantial reduction in gene transcription. Aphids containing bacteria with this mutation lost nearly all reproductive capacity after a brief exposure to $35^{\circ} \mathrm{C}$. However, when maintained at $20^{\circ} \mathrm{C}$, the same aphid strain showed a higher fecundity than aphids carrying normal Buchnera spp. The mutation arose twice spontaneously in laboratory aphid cultures and was found in a significant proportion of pea aphids collected from field sites in relatively northern, but not southern, latitudes of the United States. This is an excellent example of how an aphid's plasticity can be mediated by its resident microbiota, and may help to explain the geographic distribution of many aphid species.

In addition to their obligate primary symbiont, Buchnera spp., aphids may harbor several other vertically transmitted, facultative bacterial symbionts. The significance of these secondary strains in adaptation to herbivory was demonstrated dramatically in a study by Tsuchida and associates (2004). These researchers discovered differences in the frequencies of facultative symbiont strains in pea aphids in Japan, depending on whether the aphid was collected from vetch (Vicia sativa) or white clover (Trifolium repens). The authors used antibiotics and reinoculation by injection to manipulate the presence or absence of a symbiont called PAUS (Regiella insecticola), and showed that pea aphids perform better on white clover in the presence of PAUS than in its absence. Although it is still unclear how frequently secondary symbionts influence host use in this way, this study opens exciting possibilities for the elucidation of plant host use by aphids in natural and agricultural settings. Facultative symbionts also are likely to play important and diverse roles in other aspects of ecology and physiology of their aphid hosts, such as resistance to heat shock (Russel and Moran 2006), parasitoid attack (Oliver et al. 2003), and fungal infection (Scarborough et al. 2005), and in the production and dispersal of sexual offspring (Leonardo and Mondor 2006). It is possible that novel approaches to aphid population control could include the manipulation of these symbiotic interactions.

\section{Plant virus transmission.}

Through their feeding and migration activities, insects transmit approximately $80 \%$ of all plant viruses (Hohn 2007). Aphid- 
borne virus particles can be transmitted in a noncirculative manner, whereby the virus remains in the aphid mouthparts and the anterior alimentary tract (Pirone and Perry 2002). By contrast, viruses with a circulative transmission are absorbed in the digestive tract and cross the intestinal membrane by endocytosis before being released in the hemolymph by exocytosis. Some of these particles reach the accessory salivary glands to enter the saliva and then become reinjected into plant tissue (Gray and Gildow 2003). Virus proteins involved in transmission parameters have been well characterized (Brault et al. 2003; Moreno et al. 2005; Seddas and Boissinot 2005). To date, only a few aphid proteins have been identified as interacting in vitro with the virus particles (Li et al. 2001, Seddas et al. 2004). Some symbiotic proteins (e.g., GroEL, a chaperonin also known as symbiontin) are thought to facilitate virus circulation into the aphid hemolymph (Filichkin et al. 1997). Finally, it has been shown that the capacity of different aphid species to transmit viruses can have a strong genetic basis (Burrows et al. 2006; Dedryver et al. 2005), and a few polypeptides were found to differ in abundance between clones of this species that vector with high versus low efficiency (Papura et al. 2002). A recent study clearly identified a proteic receptor that specifically interacts with the Cauliflower mosaic virus transmitted by aphids (Uzest et al. 2007). This receptor is localized at the very tip of the stylet, in a cuticular structure, suggesting this receptor to be a cuticle protein, and genomic tools probably will facilitate the future characterization of that receptor. Thus, the biology of plant virus transmission clearly is set for rapid advancement as genomic tools on the vector side continue to develop.

\section{Parthenogenesis and polyphenism.}

Phenotypic plasticity allows animals to escape the strict genetic control of their development and respond to environmental cues with profound changes in physiology and behavior. Polyphenism is a special case of phenotypic plasticity, in which one genotype can produce several phenotypes without intermediate forms (Nijhout 1999). A major form of aphid polyphenism is the switch between viviparous parthenogenesis and sexual reproduction with eggs, depending on environmental cues. Typically, aphid species reproduce most of the year by viviparous parthenogenesis, a major factor in their destructive potential. A parthenogenetic female can produce up to 100 to 120 genetically identical embryos in approximately 10 days (Fig. 1). These live births, combined with telescoping of generations, can lead to exponential population growth in the absence of natural enemies. However, the same aphid genotype can switch from clonal to sexual reproduction in response to longer nights and cooler temperatures in autumn (Fig. 1). Oviposition of cold-resistant eggs in autumn allows aphids to survive the winter which, in higher latitudes, imposes strong selection pressure for aphids to retain their ability to reproduce sexually. This reproductive polyphenism also allows aphids to combine the immediate advantage of clonal growth conferred by parthenogenesis with the long-term advantages of recombination conferred by sexual reproduction (Simon et al. 2002).

The molecular genetic basis of reproductive polyphenism is poorly understood. However, physiological studies indicate that photoperiod-the main elicitor for reproductive mode switching-is sensed directly by the brain; neurosecretory cells transduce this signal to the oocyte stem cells, probably by

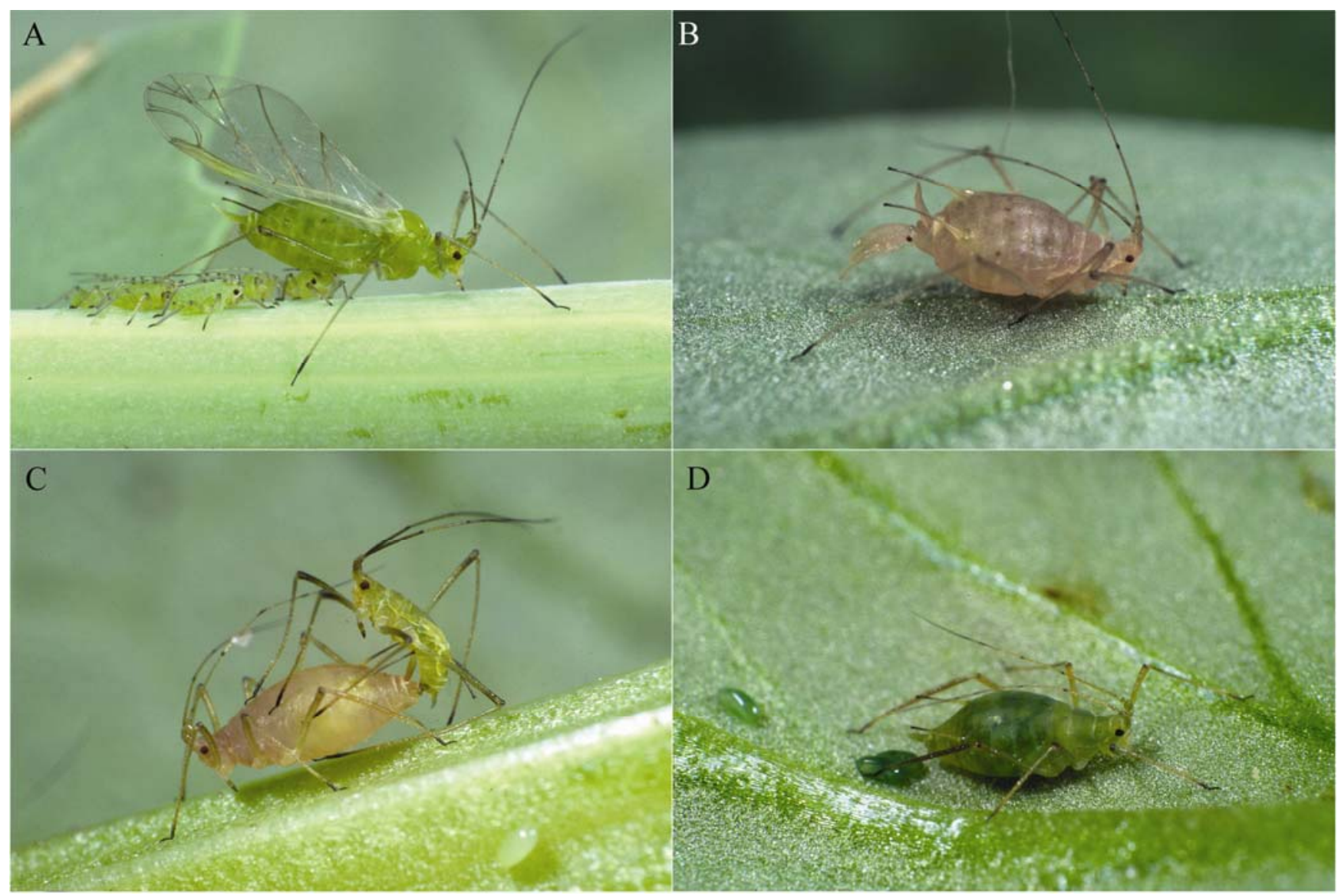

Fig. 1. Phenotypic plasticity in the pea aphid. A, Winged parthenogenetic adult female with its clonal wingless progeny. B, Wingless parthenogenetic adult female giving birth by viviparity to one of its clonal progeny. C, Mating of sexual adult female and male. D, Adult sexual female laying eggs after mating. All photographs by Bernard Chaubet (INRA-Rennes). 
hormones and other signaling molecule such as melatonin (Le Trionnaire et al. in press). Transcriptomic approaches (Tagu et al. 2004) and the use of microarrays (Le Trionnaire et al. 2007) have identified differentially accumulated transcripts expressed in the heads of pea aphids reared under long or short days. These genes, which encode structural and signaling proteins, might be involved in the early stages of the photoperiodic response. The use of microarrays allowed the proposition of new hypotheses in which the photoperiodic signals could modify the cuticle structure and increase free dopamine as putative neurosecretory material involved in photoperiodic signal transduction $(G$. Le Trionnaire, S. Jaubert-Possamei, J. Bonhomme, J. P. Gauthier, N. Prunier-Leterme, F. Legeai, S. Tanguy, J. C. Simon, and D. Tagu, unpublished). Insights regarding the molecular basis of reproductive polyphenism could offer avenues to manipulate aphid reproduction as a means of plant protection.

Another form of aphid polyphenism lies in their alternative developmental paths to produce either winged or wingless morphs at adulthood, which have different physiological and ecological properties (Fig. 1). The winged morph is specialized for migration and, therefore, plays a major role in host selection by aphids (Powell et al. 2006). Several environmental cues (e.g., crowding, deteriorating plants, natural enemies, and abiotic factors such as temperature and photoperiod) induce the production of winged aphids to anticipate habitat and resource deterioration. Evidence for a genetic basis of winged morph variation has been provided by the pea aphid, with the identification of a locus (Aphicarus [api]) controlling the presence or absence of wings in males (Braendle et al. 2006). Interestingly, this locus is genetically linked to the female wing polymorphism trait, suggesting that the same gene may be involved in the polymorphism in both sexes. Positional cloning of the api locus now could be envisaged thanks to the available assembled genome of the pea aphid. A microarray analysis of winged versus wingless pea aphids has shown a high level of expression associated with muscles formation (as expected) and energy production in the winged morph (Brisson et al. 2007). Winged males and winged females did not share the same quantitative fold change of their transcriptomic response, suggesting different trade-offs of these morphs toward wing polyphenism. This and other results from the study may provide clues to regulatory mechanisms involved in determining these morphs. A thorough understanding of the molecular events surrounding winged morph induction will help to elucidate this component of ecological adaptation and, in an agricultural context, could provide a means of interfering with a critical stage of aphid life history.

\section{New genomic resources: both sides now.}

In order to progress understanding of aphid adaptation and biotic interactions, the International Aphid Genomic Consortium
(IAGC) was launched in June 2003 in Paris, France, with the goal of developing and sharing genomic resources for aphids. Efforts are focused initially on an aphid that is currently the primary species used in laboratory investigations, the pea aphid (Table 1). Attributes of this species that make it an excellent model have been reviewed by Brisson and Stern (2006). In addition to its large size and facile culture in the lab, the pea aphid exhibits a relatively high degree of biotypic variation and already has been the subject of genetic studies to determine the inheritance and map locations of quantitative trait loci controlling differential preference and performance between alfalfa (Medicago sativa) and red clover (T. pretense) as hosts (Hawthorne and Via 2001; Via and Hawthorne 2002). These studies illustrate the potential for significant progress in unraveling the molecular mechanisms of aphid host use and selection behavior.

In March 2005, the National Human Genomic Research Institute in the United States selected the pea aphid for fullgenome sequencing (estimated at $525 \mathrm{Mb}$ ) by the Baylor College of Medicine, Houston. A growing catalogue of EST will provide essential support for the functional annotation of the pea aphid genome. In order to facilitate this annotation, a database called AphidBase has assigned over 4,500 unique pea aphid transcripts to homologous sequences in the $D$. melanogaster genome via linkage to the FlyBase website (Gauthier et al. 2007). AphidBase is now in progress to integrate genomic scaffolds of the new assembled $A$. pisum genome. Transcriptional profiling using pea aphid microarrays already has been the subject of several studies, as cited earlier in this review. More than $50 \%$ of the A. pisum transcripts remain of unknown function, and specialized cells and tissuesuch as bacteriocytes and parthenogenetic embryos-have been shown to express a specific set of transcripts (SabaterMuñoz et al. 2006). Analyses of more than 5,000 pea aphid transcripts homologous to D. melanogaster genes showed some genomic peculiarities, such as an A/T rich genome and a bias in codon usage (Rispe et al. 2007). Furthermore, a massive amplification of cathepsin B genes has been identified in several aphid species compared with other insects (Rispe et al. 2008). Cathepsin B are cystein proteases mainly located in the gut of insects: aphids always have been considered to be poor in intestinal digestion of proteins, because no proteins are present in the phloem sap. This amplification of intestinal genes with some members submitted to a relatively high evolutionary rate suggests a new role of cathepsin B in phloem-feeding insects which still remains to be characterized. The pea aphid's salivary secretome clearly will yield information on how aphids have adapted to phloem feeding. A pea aphid salivary gland EST library has been constructed, leading to the identification of a highly abundant transcript, called C002, encoding a protein of unknown function (Mutti et al. 2006). Partial

Table 1. Profile of the pea aphid Acyrthosiphon pisum

\begin{tabular}{|c|c|}
\hline Terms & Description \\
\hline Taxonomy & $\begin{array}{l}\text { Insecta, Dicondylia, Pterygota, Neoptera, Paraneoptera, Hemiptera, Sternorrhyncha, Aphidiformes, Aphidomorpha, Aphidoidea, } \\
\text { Aphididae, Aphidinae, Macrosiphini, Acyrthosiphon }\end{array}$ \\
\hline Host plants & Mostly Fabaceae (Genistae, Trifoleae, Fabeae) (e.g., Medicago, Trifolium, Pisum, and Vicia spp.) \\
\hline Distribution & Almost world-wide \\
\hline Virus transmission & Noncirculative viruses (e.g., in bean, pea, clover) and circulative viruses (e.g., Pea enation mosaic virus, Bean leaf-roll virus) \\
\hline Bacterial symbionts & $\begin{array}{l}\text { Genome of Buchnera sp. strain APS sequenced. Five facultative symbionts identified with specific polymerase chain reaction } \\
\text { primers. Microarrays for the entire genome of Buchnera are available }\end{array}$ \\
\hline \multirow[t]{4}{*}{$\begin{array}{l}\text { Stock, genetic, and } \\
\text { genomic tools }\end{array}$} & $\begin{array}{l}\text { Approximately } 900 \text { laboratory stocks of } \mathrm{A} \text {. pisum ( } 400 \text { natural genotypes and } 300 \mathrm{~F}_{2} \text { clones) characterized for several phenotypic } \\
\text { traits, including resistance to parasitoids or fungi, host plant preference and performance, reproductive modes and life cycle, or } \\
\text { defense behavior }\end{array}$ \\
\hline & Genetic map: four linkage groups based on 173 amplified fragment length polymorphism markers and $194 \mathrm{~F}_{2}$ progenies \\
\hline & Estimated genome size: $525 \mathrm{Mb}(2 n=8$ chromosomes $)$ \\
\hline & $\begin{array}{l}\text { Expressed sequence tags (EST): approximately 150,000 EST from nine different cDNA libraries (one for full-length cDNAs), } \\
\text { corresponding to a set of } n=30,000 \text { different transcripts. }\end{array}$ \\
\hline
\end{tabular}


silencing of this transcript, through RNA interference, resulted in a shortened aphid lifespan.

A significant advantage of the pea aphid model is that one of its host plants, $M$. truncatula (a close relative of alfalfa) is a model legume (Young et al. 2005). This sets the stage for the first plant-insect interaction in which the genomes of both organisms have been sequenced. Major gene resistance to the pea aphid has been described in M. truncatula and has been studied with respect to plant transcriptional responses to the aphid, tissue localization of the trait's expression, and mapping of the resistance locus (Gao et al. 2008). A closely related aphid, bluegreen aphid or blue alfalfa aphid (A. kondoi), also has been the focus of aphid resistance research in $M$. truncatula (Gao et al. 2007a and b; Klingler et al. 2005, 2007). Resistance to the bluegreen aphid is enhanced systemically by prior aphid feeding (Klingler et al. 2005) and appears to involve jasmonate, or octadecanoid, signaling (Gao et al. 2007a); this contrasts with potato aphid resistance by $\mathrm{Mi}-\mathrm{l}$ in tomato, for which salicylic acid signaling is required (Li et al. 2006) and perception of jasmonic acid is not (Bhattarai et al. 2007). Evidence suggests that $M$. truncatula's resistance traits against Acyrthosiphon spp. and another species, the spotted alfalfa aphid (Therioaphis trifolii f. maculata), are controlled by NBS-LRR resistance genes. The positional cloning of these genes may provide valuable resources to determine the molecular basis of plant recognition and signaling in response to aphid feeding, and of aphid virulence. In a broader context, the M. truncatula-pea aphid model system could be a powerful means of exploring many questions relating to the physiology, ecology, and evolution of plant interactions with phloem feeding insects.

\section{Other aphids, other insects.}

In addition to the pea aphid model, the research community will continue developing specific resources for other aphids, including the green peach aphid, Russian wheat aphid, and other major pest species. Collections of EST have been obtained for the brown citrus aphid (Toxoptera citricida) (Hunter et al. 2003), bird cherry-oat aphid (Rhopalosiphum padi) (Tagu et al. 2004), cotton-melon aphid, and green peach aphid (Figueroa et al. 2007; Ramsey et al. 2007) for a total of nearly 160,000 EST. Green peach aphid genome information will be especially useful because this species has economic importance as a major virus vector with an exceptionally broad host range (Blackman and Eastop 2000), and has been a model for studies on insecticide resistance (Anstead et al. 2005), adaptation to crop allelochemicals (Cardoza et al. 2006), and interactions with Arabidopsis (de Vos et al. 2007). Profiling of the aphid proteome is under development and has allowed the characterization of green peach aphid proteins modulated when aphids switch host plants (Francis et al. 2006; Harmel et al. 2008).

Genomic resources for other important phloem feeders also are developing. The whitefly Bemisia tabaci, for example, has its own functional genomics project, including a database of expresses sequences from the insect (viruliferous and nonviruliferous) and its endosymbiont (Leshkowitz et al. 2006). The Hessian fly (Mayetiola destructor), a gall midge of the order Diptera, is only distantly related to homopteran phloem feeders, yet it has an intimate relation with its grass hosts that resembles aspects of plant interactions with homopterans. For example, this species exhibits an exceptionally high frequency of biotype formation and engages in gene-for-gene interactions with its cereal hosts (Harris et al. 2003). Plant molecular responses to the Hessian fly have been characterized in compatible and incompatible interactions with wheat (Giovanini et al. 2006; Subramanyam et al. 2006). The genetics and molecular biology of the insect side of this interaction also are being ex- plored (Chen et al. 2004; Lobo et al. 2006; Mittapalli et al. 2006). We anticipate that the integration of data from different insect models will lead to a deeper understanding of plant defense against herbivory.

\section{Future challenges.}

One of the most important developments likely to occur in coming years is the application of genomics to the aphid's chemosensory and digestive systems. Together with salivary gland secretion, these are critical components of the aphid's interface with plant chemistry; yet relatively little is known about the molecular biology of structures such as the antennal chemosenilla, the taste receptor of the stylet food canal, or the lining of the midgut. Genomic approaches to these issues will be met with intriguing developments in aphid physiology and morphology. For example, the structure and function relationships of the antennal olfactory sensilla are revealing details about phenomena such as polyphenism of olfactory structures, wherein aphids of different morphs have different abilities to detect pheromones and plant volatiles (Park and Hardie 2002). Heritable differences in the structure of aphid antennal sensilla have been observed between different host races and, thus, are implicated in host specialization (Bernays et al. 2000). A body of literature on such topics is waiting to be built upon using knowledge of the aphid genome.

Although key genomic tools and programs are already in place, further work is needed to increase the utility of aphids as model systems. For instance, the overwintering eggs, within which the embryos develop slowly throughout the winter, represent an obstacle to rapid genetic analyses. A genetic transformation system (either stable or transitory) also is required. The initial successes of RNAi methodologies in the pea aphid, using either siRNA (Mutti et al. 2006) or dsRNA (Jaubert et al. 2007), are encouraging. Mutagenesis and collections of mutants that would allow a better characterization of key regulatory genes in aphids also are needed. Realizing these major achievements will require continuing and concerted efforts from the IAGC members in order to maintain progress in both the elucidation of fascinating biological issues (e.g., clonality) and the control of plant pests.

\section{ACKNOWLEDGMENTS}

We thank the following members of the IAGC steering committee (in alphabetical order): M. Caillaud, O. Edwards, L. Field, D. G. Ducray, S. Gray, D. Hawthorne, W. Hunter, G. Jander, N. Moran, A. Nakabachi, H. Robertson, K. Shufran, and D. Stern. This work has been supported by ANR Exdisum. C. A. Dedryver (INRA Rennes) is acknowledged for his original entomology books from the 18th century.

\section{LITERATURE CITED}

Anstead, J. A., Williamson, M. S., and Denholm, I. 2005. Evidence for multiple origins of identical insecticide resistance mutations in the aphid Myzus persicae. Insect Biochem. Mol. Biol. 3:249-256.

Baumann, P. 2005. Biology of bacteriocyte-associated endosymbionts of plant sap-sucking insects. Annu. Rev. Microbiol. 59:155-189.

Bernays, E. A., Funk, D. J., and Moran, N. A. 2000. Intraspecific differences in olfactory sensilla in relation to diet breadth in Uroleucon ambrosiae (Homoptera : Aphididae). J. Morphol. 245:99-109.

Bhattarai, K. K., Xie, Q.G., Pourshalimi, D., Younglove, T., and Kaloshian, I. 2007. Coil-dependent signaling pathway is not required for $\mathrm{Mi}$-1-mediated potato aphid resistance. Mol. Plant-Microbe Interact. 20:276-282.

Blackman, R. L., and Eastop, V. F., eds. 2000. Aphids on the World's Crops. Wiley-Interscience, Chichester, U.K.

Braendle, C., Miura T., Bickel, R., Shingleton, A. W., Kambhampati, S., and Stern, D. L. 2003. Developmental origin and evolution of bacteriocytes in the aphid-Buchnera symbiosis. PLOS Biol. 1:70-76.

Braendle, C., Davis, G. K., Brisson, J. A., and Stern, D. L. 2006. Wing dimorphism in aphids. Heredity 97:192-199.

Brault, V., Bergdoll, M., Mutterer, J., Prasad, V., Pfeffer, S., Erdinger, M., 
Richards, K. E., and Ziegler-Graff, V. 2003. Effects of point mutations in the major capsid protein of beet western yellows virus on capsid formation, virus accumulation, and aphid transmission. J. Virol. 77:3247-3256.

Brisson J. A., and Stern D. L. 2006. The pea aphid, Acyrthosiphon pisum: An emerging genomic model system for ecological, developmental and evolutionary studies. BioEssays 28:747-755.

Brisson, J. A., Davis, G. K., and Stern, D. L. 2007. Common genome-wide patterns of transcript accumulation underlying the wing polyphenism and polymorphism in the pea aphid (Acyrthosiphon pisum). Evol. Dev. 9:338-346.

Brotman, Y., Silberstein, L., Kovalski, I., Perin, C., Dogimont, C., Pitrat, M., Klingler, J., Thompson, G. A., and Perl-Treves, R. 2002. Resistance gene homologues in melon are linked to genetic loci conferring disease and pest resistance. Theor. Appl. Genet. 104:1055-1063.

Burrows, M. E., Caillaud, M. C., Smith, D. M., Benson, E. C., Gildow, F. E., and Gray, S. M. 2006. Genetic regulation of polerovirus and luteovirus transmission in the aphid Schizaphis graminum. Phytopathology 96:828-837.

Cardoza, Y. .J, Wang, S. F., Reidy-Crofts, J., and Edwards, O. R. 2006 Phloem alkaloid tolerance allows feeding on resistant Lupinus angustifolius by the aphid Myzus persicae. J. Chem. Ecol. 32:1965-1976.

Casteel, C., Walling, L. L., and Paine T. 2006. Behavior and biology of the tomato psyllid, Bactericerca cockerelli, in response to the Mi-1.2 gene. Entomol. Exp. Appl. 121:67-72.

Cevik, V., and King, G. J. 2002. Resolving the aphid resistance locus $S d-1$ on a BAC contig within a sub-telomeric region of Malus linkage group 7. Genome 45:939-945

Chen, M. S., Fellers, J. P., Stuart, J. J., Reese, J. C. and Liu, X. 2004. A group of related cDNAs encoding secreted proteins from Hessian fly (Mayetiola destructor (Say)) salivary glands. Insect Mol. Biol. 13:101108

Cherqui, A., and Tjallingii, W. F. 2000. Salivary proteins of aphids, a pilot study on identification, separation and immunolocalisation. J. Insect Physiol. 46:1177-1186.

Dedryver, C. A., Riault, G., Tanguy, S., Le Gallic, J. F., Trottet, M., and Jacquot, E. 2005. Intra-specific variation and inheritance of BYDV-PAV transmission in the aphid Sitobion avenae. Eur. J. Plant Pathol. 111:341354

Derron, J. O., and Goy, G. 1993. Le puceron du Pois (Acythosiphon pisum): Biologie, nuisibilité et moyen de lutte sur les protéagineux. Rev. Suisse Agric. 25:43-47.

De Vos, M., Kim, J. H., and Jander, G. 2007. Biochemistry and molecular biology of Arabidopsis-aphid interactions. BioEssays 29:871-883.

Dixon, A. F. G. 1998. Aphid Ecology: An Optimization Approach, Second ed. Chapman and Hall, London.

Dogimont, C., Bendahmane, A., Pitrat, M., Burget-Bigeard, E., Hagen, L. et al. 2007. Gene resistant to Aphis gossypii, United States of America patent no. 0070016977

Douglas, A. E. 2003. The nutritional physiology of aphids. Adv. Insect Physiol. 31:73-140.

Douglas, A. E. 2006. Phloem-sap feeding by animals: Problems and solutions. J. Exp. Bot. 57:747-754.

Dunbar, H. E., Wilson, A. C. C., Ferguson, N. R., and Moran, N. A. 2007 Aphid thermal tolerance is governed by a point mutation in bacterial symbionts. PLOS Biol. 5:1006-1015.

Figueroa, C. C., Prunier-Leterme, N., Rispe, C., Sepúlveda, F., FuentesContreras, E., Sabater-Muñoz, B., Simon, J. C., and Tagu, D. 2007. Annotated expressed sequence tags and xenobiotic detoxification in the aphid Myzus persicae (Sulzer). Insect Sci. 14:29-45.

Filichkin, S. A., Brumfield, S., Filichkin, T. P., and Young, M. J. 1997. In vitro interactions of the aphid endosymbiotic SymL chaperonin with barley yellow dwarf virus. J. Virol. 71:569-577.

Francis, F., Gerkens, P., Harmel, N., Mazzucchelli, G., De Pauw, E., and Haubruge, E. 2006. Proteomics in Myzus persicae: Effect of aphid host plant switch. Insect Biochem. Mol. Biol. 36:219-227.

Gao, L. L., Anderson, J. P., Klingler, J. P., Nair, R. M., Edwards, O. R., and Singh, K. B. 2007a. Involvement of the octadecanoid pathway in bluegreen aphid resistance in Medicago truncatula. Mol. Plant-Microbe Interact. 20:82-93.

Gao, L.-L., Horbury, R., Nair, R. M., Singh, K. B., and Edwards, O. R. 2007b. Characterization of resistance to multiple aphid species (Hemiptera: Aphididae) in Medicago truncatula. Bull. Entomol. Res. 97:41-48.

Gao, L. L., Klingler, J. P., Anderson, J. P., Edwards, O. R., and Singh, K. B. 2008. Characterization of pea aphid resistance in Medicago truncatula. Plant Physiol. In press. DOI:10.1104/pp.107.111971.

Gauthier, J. P., Legeai, F., Zasadzinski, A., Rispe, C., and Tagu, D. 2007. AphidBase: A database for aphid genomic resources. Bioinformatics 23:783-784.

Giovanini, M. P., Puthoff, D. P., Nemacheck, J. A., Mittapalli, O., Saltzmann, K. D., Ohm, H. W., Shukle, R. H., and Williams, C. E. 2006. Gene-for- gene defense of wheat against the hessian fly lacks a classical oxidative burst. Mol. Plant-Microbe Interact. 19:1023-1033.

Goggin, F. L. 2007. Plant-aphid interactions: Molecular and ecological perspectives. Curr. Opin. Plant Biol. 10:399-408.

Gray, S., and Gildow, F. E. 2003. Luteovirus-aphid interactions. Annu. Rev. Phytopathol. 41:539-566.

Harmel, N., Létocart, E., Cherqui, A., Giordanengo, P., Mazzucchelli, G., Guillonneau, F., De Pauw, E., Haubruge, E., and Francis, F. 2008. Indentification of aphid salivary proteins: A proteomic investigation of Myzus persicae. Insect Mol. Biol. 17:165:174.

Harris, M. O., Stuart, J. J., Mohan, M., Nair, S., Lamb, R. J., and Rohfritsch, O. 2003. Grasses and gall midges: Plant defense and insect adaptation. Annu. Rev. Entomol. 48:549-577.

Hawthorne, D. J., and Via, S. 2001. Genetic linkage of ecological specialization and reproductive isolation in pea aphids. Nature 412:904-907.

Hohn, T. 2007. Plant virus transmission from the insect point of view. Proc. Nat. Acad. Sci. U.S.A. 104:17905-17906.

Hunter, W. B., Dang, P. M., Bausher, M. G., Chaparro, J. X., McKendree, W., Shatters, R. G., McKenzie, C. L., and Sinisterra, X. H. 2003. Aphid biology: Expressed genes from the alate Toxoptera citricida, the brown citrus aphid. J. Insect Sci. 3:23.

Jaubert, S., Le Trionnaire, G., Bonhomme, J., Christophides, G. K., Rispe, C., and Tagu, D. 2007. Gene knockdown by RNAi in the pea aphid Acyrthosiphon pisum. BMC Biotechnol. 7:63.

Kaloshian I., and Walling L. L. 2005. Hemipterans as plant pathogens. Annu. Rev. Phytopathol. 43:491-521.

Kempema, L. A., Cui, X. P., Holzer, F. M., and Walling, L. L. 2007. Arabidopsis transcriptome changes in response to phloem-feeding silverleaf whitefly nymphs. Similarities and distinctions in responses to aphids. Plant Physiol. 143:849-865.

Klingler, J., Creasy, R., Gao, L., Nair, R. M., Calix, A. S., Spafford Jacob, H., Edwards, O. R., and Singh, K. B. 2005. Aphid resistance in Medicago truncatula involves antixenosis and phloem-specific, inducible antibiosis, and maps to a single locus flanked by NBS-LRR resistance gene analogs. Plant Physiol. 137:1445-1455.

Klingler, J. P, Edwards, O. R., and Singh, K. B. 2007. Independent action and contrasting phenotypes of resistance genes against spotted alfalfa aphid and bluegreen aphid in Medicago truncatula. New Phytol. 173:630-640

Knoblauch, M., Peters, W. S., Ehlers K., and Van Bel, A. J. E. 2001. Reversible calcium-regulated stopcocks in legume sieve tubes. Plant Cell 13:1221-1230.

Lapitan, N. L. V., Li, Y. C., Peng, J. H., and Botha, A. M. 2007. Fractionated extracts of Russian wheat aphid eliciting defense responses in wheat. J. Econ. Entomol. 100:990-999.

Leonardo, T. E., and Mondor, E. B. 2006. Symbiont modifies host life-history traits that affect gene flow. Proc. R. Soc. B Biol. Sci. 273:10791084

Leshkowitz, D., Gazit, S., Reuveni, E., Ghanim, M., Czosnek, H., McKenzie, C., Shatters, R. L., Jr., and Brown, J. K. 2006. Whitefly (Bemisia tabaci) genome project: Analysis of sequenced clones from egg, instar, and adult (viruliferous and non-viruliferous) cDNA libraries. BMC Genomics 7:79.

Le Trionnaire, G., Jaubert, S., Sabater-Muñoz, B., Benedetto, A., Bonhomme, J., Prunier-Leterme, N., Martinez-Torres, D., Simon, J. C. and Tagu, D. 2007. Seasonal photoperiodism regulates the expression of cuticular and signalling protein genes in the pea aphid. Insect Biochem. Mol. Biol. 37:1094-1102.

Le Trionnaire, G. Hardie, J., Jaubert-Possamai, S., and Tagu, D. Shifting from clonal to sexual reproduction in aphids: Physiological and developmental aspects. Biol. Cell. In press.

Li, C. Y., Cox-Foster, D., Gray, S. M., and Gildow, F. E. 2001. Vector specificity of Barley yellow dwarf virus (BYDV) transmission: Identification of potential cellular receptors binding BYDV-MAV in the aphid Sitobion avenae. Virology 286:125-133.

Li, Q., Xie, Q.-G., Smith-Becker, J., Navarre, D. A., and Kaloshian, I. 2006. Mi-1-mediated aphid resistance involves salicylic acid and mitogen-activated protein kinase signaling cascades. Mol. Plant-Microbe Interact. 19:655-664

Lister, R. M., and Ranoeri, R. 1995. Distribution and economic importance of barley yellow dwarf. Pages 29-53 in: Barley Yellow Dwarf: 40 Years of Progress. C. J. D'Arcy and P. Burnett, eds American Phytopathological Society Press, St. Paul, MN, U.S.A.

Lobo, N. F., Behura, S. K., Aggarwal, R., Chen, M. S., Collins, F. H., and Stuart, J. J. 2006. Genomic analysis of a $1 \mathrm{Mb}$ region near the telomere of Hessian fly chromosome X2 and avirulence gene vH13. BMC Genomics 7:7.

Marcovitch, S. 1924. The migration of the Aphididae and the appearance of the sexual forms as affected by the relative length of daily light exposure. J. Agric. Res. 27:513-522. 
Miles, P. W. 1999. Aphid saliva. Biol. Rev. 74:41-85.

Mittapalli, O., Shukle, R. H. Sardesai, N., Giovanini, M. P., and Williams, C. E. 2006. Expression patterns of antibacterial genes in the Hessian fly. J. Insect Physiol. 52:1143-1152.

Moran, N. A., Dunbar, H. E., and Wilcox, J. L. 2005. Regulation of transcription in a reduced bacterial genome: Nutrient-provisioning genes of the obligate symbiont Buchnera aphidicola. J. Bacteriol. 187:4229-4237.

Moreno, A., Hebrard, E., Uzest, M., Blanc, S., and Fereres, A. 2005. A single amino acid position in the helper component of cauliflower mosaic virus can change the spectrum of transmitting vector species. J. Virol. 79:13587-13593.

Morgan, T. H. 1910. The chromosomes in the parthenogenetic and sexual eggs of phylloxerans and aphids. Proc. Soc. Exp. Biol. N. Y. 7:161-162.

Mutti, N. S., Park, Y., Reese, J. C., and Reeck, G. R. 2006. RNAi knockdown of a salivary transcript leading to lethality in the pea aphid (Acyrthosiphon pisum). J. Insect Sci. 6:38.

Nakabachi, A., Shigenobu, S., Sakazume, N., Shiraki, T., Hayashizaki, Y., Carninci, P., Ishikawa, H., Kudo, T., and Fukatsu, T. 2005. Transcriptome analysis of the aphid bacteriocyte, the symbiotic host cell that harbors an endocellular mutualistic bacterium, Buchnera. Proc. Nat. Acad. Sci. U.S.A. 102:5477-5482.

Nijhout, H. F. 1999. Control mechanisms of polyphenic development in insects, BioSciences 49:181-192.

Nombela, G., Williamson, V. M., and Muniz, M. 2003. The root-knot nematode resistance gene $\mathrm{Mi}-1.2$ of tomato is responsible for resistance against the whitefly Bemisia tabaci. Mol. Plant-Microbe Interact. 16:645-649.

Oliver, K. M., Russell, J. A., Moran, N. A., Hunter, M. S. 2003. Facultative bacterial symbionts in aphids confer resistance to parasitic wasps. Proc. Nat. Acad. Sci. U.S.A. 100:1803-1807.

Papura, D., Jacquot, E., Dedryver, C. A., Luche, S., Riault, G., Bossis, M., and Rabilloud, T. 2002. Two-dimensional electrophoresis of proteins discriminates aphid clones of Sitobion avenae differing in BYDV-PAV transmission. Arch. Virol. 147:1881-1898.

Park, K. C., and Hardie, J. 2002. Functional specialisation and polyphenism in aphid olfactory sensilla. J. Insect Physiol. 48:527-535.

Pegadaraju V., Knepper C., Reese J., and Shah J. 2005. Premature leaf senescence modulated by the Arabidopsis PHYTOALEXIN DEFICIENT4 gene is associated with defense against the phloem-feeding green peach aphid. Plant Physiol. 139:1927-1934.

Pegadaraju, V., Louis, J., Singh, V., Reese, J. C., Bautor, J., Feys, B. J., Cook, G., Parker, J. E., and Shah, J. 2007. Phloem-based resistance to green peach aphid is controlled by Arabidopsis PHYTOALEXIN DEFICIENT4 without its signaling partner ENHANCED DISEASE SUSCEPTIBILITY1. Plant J. 52:332-341

Pirone, T. P., and Perry, K. L. 2002. Aphids-non persistent transmission. Adv. Bot. Res. 36:1-19.

Powell, G., Tosh, C. R., and Hardie, J. 2006. Host plant selection by aphids: Behavioral, evolutionary, and applied perspectives. Annu. Rev. Entomol. 51:309-330.

Puterka, G. J., and Burton, R. L. 1991. Aphid genetics in relation to host plant resistance. Pages 59-69 in: Proceedings of Aphid-Plant Interactions: Populations to Molecules. D. C. Peters, J. A. Webster, and C. S. Chlouber, eds. U. S. Dep. Agric. Agric. Res. Serv. Oklahoma State University.

Ramsey, J. S., Wilson, A. C. C., de Vos, M., Sun, Q., Tamborindeguy, C., Winfield, A., Malioch, G., Smith, D.W., Fenton, B., Gray, S. M., and Jander, G. 2007. Genomic resources for Myzus persicae: EST sequencing, SNP identification, and microarray design. BMC Genomics 8:423.

Reymond, N. A., Calevro, F., Viñuelas, J., Morin, N, Rahbé, Y., Febvay, G., Laugier, C., Douglas, A., Fayard, J. M., and Charles, H. 2006. Different levels of transcriptional regulation to trophic constraints in the reduced genome of Buchnera aphidicola APS. Appl. Environ. Microbiol. 72:7760-7766.

Rispe, C., Legeai, F., Gauthier, J. P., and Tagu, D. 2007. Strong heterogeneity in nucleotidic composition and codon bias in the pea aphid (Acyrthosiphon pisum) shown by EST-Based coding genome reconstruction. J. Mol. Evol. 65:413-424.

Rispe, C. Kutsukake, M., Doublet, V., Hudaverdian, S., Legeai, F., Simon, J. C., Tagu, D., and Fukatsu, T. 2008. Large gene family expansion and variable selective pressures for cathepson B in aphids. Mol. Biol. Evol. 25:5-17.

Rossi, M., Goggin, F. L., Milligan, S. B., Kaloshian, I., Ullman, D. E., and Williamson, V. M. 1998. The nematode resistance gene $M i$ of tomato confers resistance against the potato aphid. Proc. Nat. Acad. Sci. U.S.A. 95:9750-9754.

Russell, J. A., and Moran, N. A. 2006. Costs and benefits of symbiont infection in aphids: Variation among symbionts and across temperatures Proc. R. Soc. B Biol. Sci. 273:603-610.

Sabater-Muñoz, B., Legeai, F., Rispe, C., Bonhomme, J., Dearden, P. K.,
Dossat, C., Duclert, A., Gauthier, J. P., Giblot Ducray, D., Hunter, W. Dang, P., Kambhampati S., Martinez-Torres, D., Cortes, T., Moya, A., Nakabachi, A., Philippe, C., Prunier-Leterme, N., Rahbé, Y., Simon, J. C., Stern, D. L., Wincker, P., and Tagu, D. 2006. Large scale gene discovery in the pea aphid Acyrthosiphon pisum (Hemiptera). Genome Biol. 7:R21.1-R21.11.

Scarborough, C. L., Ferrari, J., and Godfray, H. C. J. 2005. Aphid protected from pathogen by endosymbiont. Science 310:1781.

Seah, S., Sivasithamparam, K., Karakousis, A., and Lagudah, E. S. 1998. Cloning and characterisation of a family of disease resistance gene analogs from wheat and barley. Theor. Appl. Genet. 97:937-945.

Seddas, P., and Boissinot, S. 2005. Glycosylation of beet western yellows virus proteins is implicated in the aphid transmission of the virus. Arch. Virol. 151:967-984.

Seddas, P., Boissinot, S., Strub, J. M., Van Dorsselaer, A., Van Regenmortel, M. H. V., and Pattus, F. 2004. Rack-1, GAPDH3, and actin: Proteins of Myzus persicae potentially involved in the transcytosis of beet western yellows virus particles in the aphid. Virology 325:399-412.

Shigenobu, S., Watanabe, H., Hattori, M., Sakaki, Y., and Ishikawa, H. 2000. Genome sequence of the endocellular bacterial symbiont of aphids Buchnera sp. APS. Nature 407:81-86.

Simon, J. C., Rispe, C., and Sunnucks, P. 2002. Ecology and evolution of sex in aphids. Trends Ecol. Evol. 17:34-39.

Smith, C. M., Belay, T., Stauffer, C., Stary, P., Kubeckova, I., and Starkey, S. 2004. Identification of Russian wheat aphid (Homoptera: Aphididae) biotypes virulent to the Dn4 resistance gene. J. Econ. Entomol. 97:112-117.

Subramanyam, S. Sardesai, N., Puthoff, D. P., Meyer, J. M., Nemacheck, J. A., Gonzalo, M., and Williams, C. E. 2006. Expression of two wheat defense-response genes, $H f r-1$ and Wci-1, under biotic and abiotic stresses. Plant Sci. 170:90-103.

Tagu, D., Prunier-Leterme, N., Legeai, F., Gauthier, J. P., Duclert, A., Sabater-Muñoz, B., Bonhomme, J., and Simon, J. C. 2004. Annotated expressed sequence tags for studies of the regulation of reproductive modes in aphids. Insect Biochem. Mol. Biol. 34:809-822.

Tamas, I., Klasson, L., Canback, B., Naslund, A. K., Eriksson, A. S., Wernegreen, J. J., Sandstrom, J. P., Moran, N. A., and Andersson, S. G. E. 2002. 50 million years of genomic stasis in endosymbiotic bacteria. Science 296:2376-2379.

Tatchell, G. M. 1991. Monitoring and forecasting aphid problems. Pages 215-231 in: Proceedings of Aphid-Plant Interactions: Populations to Molecules. D. C. Peters, J. A. Webster, and C. S. Chlouber, eds. U. S. Dep. Agric. Agric. Res. Serv. Oklahoma State University.

Thompson, G. A., and Goggin, F. L. 2006. Transcriptomics and functional genomics of plant defence induction by phloem-feeding insects. J. Exp. Bot. 57:755-766.

Tjallingii, W. F. 2006. Salivary secretions by aphids interacting with proteins of phloem wound responses. J. Exp. Bot. 57:739-745.

Tsuchida, T., Koga, R., and Fukatsu, T. 2004. Host plant specialization governed by facultative symbiont. Science 303:1989.

Uzest, M., Gargani, D., Drucker, M., Hébrard, E., Garzo, E., Candresse, T., Fereres, A., and Blanc, S. 2007. A protein key to plant virus transmission at the tip of the insect vector stylet. Proc. Nat. Acad. Sci. U.S.A. 104:17959-17964.

Via, S., and Hawthorne, D. J. 2002. The genetic architecture of ecological specialization: Correlated gene effects on host use and habitat choice in pea aphids. Am. Nat. 159:S76-88.

Will, T., and van Bel, A. J. E. 2006. Physical and chemical interactions between aphids and plants. J. Exp. Bot. 57:729-737.

Will, T., Tjallingii, W. F., Thonnessen, A., and van Bel, A. J. E. 2007. Molecular sabotage of plant defense by aphid saliva. Proc. Nat. Acad. Sci. U.S.A. 104:10536-10541.

Wilson, A. C. C., Dunbar, H. E., Davis, G. K., Hunter, W. B., Stern, D. L., and Moran, N. A. 2006. A dual-genome microarray for the pea aphid, Acyrthosiphon pisum, and its obligate bacterial symbiont, Buchnera aphidicola. BMC Genomics 7:50.

Young, N. D., Cannon, S. B., Sato, S., Kim, D., Cook, D. R., Town, C. D., Roe, B. A., and Tabata, S. 2005. Sequencing the genespaces of Medicago truncatula and Lotus japonicus. Plant Physiol. 137:1174-1181.

Zarate, S. I., Kempema, L. A., and Walling, L. L. 2007. Silverleaf whitefly induces salicylic acid defenses and suppresses effectual jasmonic acid defenses. Plant Physiol. 143:866-875.

\section{AUTHOR-RECOMMENDED INTERNET RESOURCES}

Baylor College of Medicine Pea Aphid Genome Project website: www.hgsc.bcm.tmc.edu/projects/aphid

International Aphid Genomics Consortium (IAGC) AphidBase sites: www.aphidbase.com and w3.rennes.inra.fr/aphidbase 